\title{
Pre- and Postharvest Treatments to Control Green Mold of Citrus Fruit During Ethylene Degreening
}

\author{
J. L. Smilanick, United States Department of Agriculture-Agricultural Research Service, San Joaquin Agricultural \\ Sciences Center, Parlier, CA 93648; M. F. Mansour, Department of Horticulture, Menofiya University, Shebin El- \\ Kom, Egypt; and D. Sorenson, Fruit Grower's Supply Co., Orange Cove, CA 93646
}

\begin{abstract}
Smilanick, J. L., Mansour, M. F., and Sorenson, D. 2006. Pre- and postharvest treatments to control green mold of citrus fruit during ethylene degreening. Plant Dis. 90:89-96.

Two approaches, fungicide applications to trees before harvest and drenching fruit after harvest, were evaluated to minimize postharvest green mold, caused by Penicillium digitatum, particularly among fruit subjected to ethylene gas after harvest, a practice termed "degreening" that eliminates green rind color. Preharvest applications of thiophanate methyl (TM) controlled postharvest green mold consistently. In five tests, green mold among degreened orange fruit was $16 \%$ when TM was applied 1 week before harvest; whereas, among fruit not treated, the incidence was $89.5 \%$. Thiabendazole (TBZ) applied to harvested fruit in bins before degreening also was very effective. TBZ effectiveness was enhanced by mild heating $\left(41^{\circ} \mathrm{C}\right)$, adding sodium bicarbonate, and immersing fruit, rather than drenching them, with the solution. With these measures, an isolate of $P$. digitatum with a high level of TBZ resistance was significantly controlled. In semicommercial tests with naturally inoculated fruit, TBZ and sodium bicarbonate treatment reduced green mold incidence from $11 \%$ among untreated orange fruit to $2 \%$. TBZ residues in lemon fruit at $41^{\circ} \mathrm{C}$ were about twice those treated at $24^{\circ} \mathrm{C}$. Neither TM before harvest nor TBZ and sodium bicarbonate applied after harvest influenced green color removal during degreening of orange fruit. Sodium bicarbonate slightly reduced the rate of lemon color change.
\end{abstract}

Additional keywords: heat treatment

Citrus fruit harvested early in the season are often of acceptable internal maturity but are not of optimum rind color for commercial sale. "Degreening" is a common commercial practice in many parts of the world used to enhance the appeal of the fruit to consumers by the removal of the green color from the peel of orange and lemon fruit by exposure of the fruit immediately after harvest to ethylene gas. Rapid chlorophyll degradation and some carotenoid synthesis occurs during the treatment, which consists of exposure to ethylene at 5 to $10 \mu \mathrm{liter}^{-1}$ at 90 to $95 \%$ relative humidity for 1 to 5 days at 20 to $22^{\circ} \mathrm{C}$ in California or 28 to $29^{\circ} \mathrm{C}$ in Florida $(13,18,30)$. The environment during degreening in California is optimal for the development of green mold, caused by Penicillium digitatum (Pers.:Fr.) Sacc. Conversely, in Florida, degreening is conducted at temperatures that inhibit this pathogen, so that green mold incidence is of less importance

Corresponding author: J. L. Smilanick

E-mail: jsmilanick@fresno.ars.usda.gov

Accepted for publication 23 August 2005.

DOI: 10.1094/PD-90-0089

This article is in the public domain and not copyrightable. It may be freely reprinted with customary crediting of the source. The American Phytopathological Society, 2006. there (26). We have observed that losses by $P$. digitatum in California are typically 2 to $4 \%$ during degreening, but they may exceed $30 \%$ and be a serious problem during disease-conducive years, such as those where heavy rains occur before harvest, or when split fruit or other rind injuries occur on the trees at a high frequency. Protection of the fruit from postharvest decay during degreening is difficult because the fruit have not passed through a packing line, where fungicide applications typically are done, before they are exposed to ethylene gas. Degreening is conducted before the fruit are dumped from the field bins because waxing, cleaning, and other handling can reduce its effectiveness $(8,20,23)$. Drenches of hot water or thiabendazole (TBZ), without other handling, did not influence the degreening rates of Hamlin orange fruit (8).

Approaches employed to minimize losses during degreening include fungicides applied to trees before harvest $(4,10,24,31,45)$, drenching fruit in field bins with fungicides (10), and thermal curing treatments combined with degreening (46). In Florida, the first two approaches commonly are employed but they are not used to specifically control green mold. Some control of postharvest green mold occurs as a consequence of grove fungicide applications, which typically are done not to control green mold after har- vest but to control melanose, greasy spot, postbloom fruit drop, and other grove diseases common in Florida but not California (42). Diplodia stem-end rot, caused by Lasiodiplodia theobromae (Pat.) Griffon \& Maubl., is the principle postharvest pathogen of concern on degreened citrus fruit in Florida (6), and applications of benomyl and thiophanate methyl in groves before harvest are effective to control it after harvest (31). Bin drenching before degreening in Florida with TBZ is done primarily to control stem-end rot, but some control of anthracnose and green and blue Penicillium molds also occurs $(10,13)$. Interest in implementing these practices in California has increased recently because warm rains have occurred early in some harvest seasons and unusually large numbers of navel orange fruit split or cracked before harvest, which together have caused green mold losses during degreening to become unacceptably high in many packinghouses.

We evaluated two approaches to manage green mold, the primary postharvest disease that causes losses during degreening in California. An effective preharvest fungicide with continuing activity that persists to provide postharvest decay control after harvest would be a useful management tool for citrus growers $(31,45)$. Therefore, we applied fungicides to trees one or more weeks before harvest and their effectiveness to control green mold on inoculated and degreened fruit was determined. The second approach was to evaluate drenching bins of harvested fruit with a fungicide before degreening. An effective postharvest fungicide that protects fruit during degreening would be a useful option for packinghouse managers. The fungicide selected for this purpose was TBZ, because of the long, successful use of this material in bin drenchers in Florida. To maximize TBZ effectiveness, we evaluated this material alone or in combination with chlorine, sodium bicarbonate, and heat.

\section{MATERIALS AND METHODS}

Pathogen culture. Two $P$. digitatum isolates, TBZ-sensitive (TBZ-s) and TBZresistant (TBZ-r) isolates M6R and D201, respectively, were cultured 1 to 2 weeks at $25^{\circ} \mathrm{C}$ on potato dextrose agar (PDA; Difco Laboratories, Detroit). Spores of each isolate, which originated from a single spore obtained from a lesion on infected fruit, were stored at $-70^{\circ} \mathrm{C}$ on silica gel 
and recultured on PDA when needed. Spores of TBZ-s isolate M6R would not germinate on TBZ-amended PDA containing the fungicide at $0.1 \mu \mathrm{g} / \mathrm{ml}$, whereas those of TBZ-r isolate D201 would germinate on PDA amended with TBZ at 15.0 $\mu \mathrm{g} / \mathrm{ml}$. Growth of an isolate on PDA amended with $\mathrm{TBZ}$ at $\geq 10 \mu \mathrm{g} / \mathrm{ml}$ indicates its resistance is commercially significant (13). Green mold caused by inoculation of TBZ-s isolate M6R on lemon was controlled by TBZ applications of $500 \mu \mathrm{g} / \mathrm{ml}$, a rate typically applied in California to citrus fruit, whereas this rate did not control TBZ-r isolate D201 (data not shown). Spores were collected by adding $5 \mathrm{ml}$ of sterile, deionized water containing $0.05 \%$ Triton X-100 to the petri dish colony, rubbing the surface with a sterile glass rod, and passing the suspension through two layers of cheese cloth. The suspension was diluted with water to an absorbance of 0.1 at $425 \mathrm{~nm}$, determined with a spectrophotometer, yielding about $1 \times 10^{6}$ spores $/ \mathrm{ml}$ (17).

Fruit and inoculation procedures. 'Eureka' lemon (from Ventura County) and navel orange (from the San Joaquin Valley) were used in these experiments. Within 1 or 2 days after harvest, fruit were randomized, blemished fruit were removed, and each was inoculated using $P$. digitatum isolates M6R or D201 by dipping a steel rod with a 1-mm-wide and 2-mm-long tip into a suspension of about $1 \times 10^{6}$ spores/ml, and immediately making a single wound in each fruit with the rod. This is a recommended procedure for evaluating decay control methods for green and blue molds on citrus fruit (17); treatments that control infections made by this method generally work effectively against these diseases on naturally infected fruit.

Preharvest fungicide applications. Fungicides applied as grove sprays to navel orange trees before harvest were (i) azoxystrobin (Abound, 22.9\% azoxystrobin; Syngenta Corp., Wilmington, DE) applied at $0.25 \mathrm{~kg} / \mathrm{ha}$; (ii) a mixture of cyprodinil and fludioxonil (Switch, 37.5\% cyprodinil and $25 \%$ fludioxonil; Syngenta Corp., Greenboro, NC) applied at 0.40 and $0.27 \mathrm{~kg} / \mathrm{ha}$, respectively; (iii) pyraclostrobin (Headline, 23.6\% pyraclastrobin; BASF Corporation, Research Triangle Park, NC) applied at $0.25 \mathrm{~kg} / \mathrm{ha}$; (iv) a mixture of boscalid and pyraclostrobin (Pristine, $25.2 \%$ boscalid and $12.5 \%$ pyraclostrobin; BASF Corporation) applied at 0.29 and $0.14 \mathrm{~kg} / \mathrm{ha}$, respectively; and (v) thiophanate methyl (Topsin M WSB, 70\% thiophanate methyl; CerexAgri, King of Prussia, PA) applied at $1.58 \mathrm{~kg} / \mathrm{ha}$.

Fungicides were applied to navel orange trees with internally mature fruit with a dark green rind in five tests.

Test 1. One of five fungicides at rates previously described or water alone was applied at 2,800 liters/ha to 10 replicate Atwood navel orange trees with a 750-liter- capacity gasoline-engine-powered handgun sprayer. Fruit were harvested from all treatments once 1 week later.

Test 2. Thiophanate methyl at $1.58 \mathrm{~kg} / \mathrm{ha}$ or water alone was applied at 933 liters/ha to 10 replicate Washington navel orange trees by 25 -liter-capacity gasoline-enginepowered handgun backpack sprayer. Fruit were harvested from the water and fungicide treatments once 1 week later.

Test 3. Thiophanate methyl at $1.58 \mathrm{~kg} / \mathrm{ha}$ or water alone was applied at $2,800 \mathrm{li}-$ ters/ha in a commercial grove to 20 Washington navel orange trees by 2,000-litercapacity commercial air-blast sprayer. Fruit were harvested from the water and fungicide treatments once 1 week later.

Test 4 . Thiophanate methyl at $1.58 \mathrm{~kg} / \mathrm{ha}$ or water alone was applied at 4,665 liters/ha to 20 Washington navel orange trees by a 2,000-liter-capacity commercial air-blast sprayer. Fruit were harvested from the water and fungicide treatments $1,3,5$, and 7 weeks after treatment.

Test 5. Thiophanate methyl at $1.58 \mathrm{~kg} / \mathrm{ha}$ or water alone was applied at 2,800 liters/ha to 10 replicate Atwood navel orange trees by a 500-liter-capacity gasolineengine-powered handgun sprayer. Fruit were harvested from the water and fungicide treatments 1,4 , and 7 weeks after treatment.

Tests 1, 2, and 5 used a randomized complete block design and were conducted at the University of California, Lindcove Research and Extension Center, Tulare County. Tests 3 and 4 were applied to two rows of 10 trees each separated by three untreated rows of trees. Test 3 was conducted in a commercial grove in Kern County, California. Test 4 was conducted at the University of California, Lindcove Research and Extension Center, Tulare County. Rainfall was recorded in California Irrigation Management Information System weather stations 86 or 138 that were located not more than $0.5 \mathrm{~km}$ from the groves.

On the day of harvest, an equal number of fruit were clipped by hand from trees and inoculated within 1 or $2 \mathrm{~h}$ and degreened for 3 days in ethylene at $5 \mu \mathrm{l} /$ liter at $20^{\circ} \mathrm{C}$ when required. After storage for one additional week at $20^{\circ} \mathrm{C}$, the number of infected fruit were counted. Each treatment included four replicates of 60 to 75 orange fruit each. In tests 4 and 5, in addition to 1 week after fungicide or water applications, fruit were harvested at later intervals up to 7 weeks after spray application. In test 1 , color changes of the fruit during ethylene degreening were recorded. In all tests except test 1 , three replicate samples of six fruit each were collected periodically and thiophanate methyl residues were determined using a procedure described later.

Postharvest fungicides applied to fruit. All fruit were inoculated as previously described and stored at $20^{\circ} \mathrm{C}$ about
$24 \mathrm{~h}$ before treatments were applied. Unless indicated otherwise, fruit were immersed in 15 liters of each solution contained within 22-liter-capacity stainless steel tanks, where the temperature was maintained by a computer-controlled electric heating element and thermostat, and the solution was stirred continuously. Solution contents included TBZ (98.5\% a.i., Fresh Ban 4000; Fresh Mark Corp., Ocoee, FL), sodium hypochlorite (Sigma-Aldrich, Chicago), and sodium bicarbonate (Na$\mathrm{HCO}_{3}$; Sigma-Aldrich). Sodium hypochlorite content expressed as free chlorine, the sum of $\mathrm{OCl}^{-}+\mathrm{HOCl}$, was measured by the DPD method (38) with a colorimeter (Model DR890; Hach, Inc. Loveland, CO).

Temperature influence on postharvest TBZ effectiveness. Light-green lemon fruit were inoculated with TBZ-s isolate M6R as described previously. After $24 \mathrm{~h}$, they were immersed for $60 \mathrm{~s}$ in aqueous solutions of TBZ at $0,25,50$, and 100 $\mu \mathrm{g} / \mathrm{ml}$ at temperatures of $16,27,38$, or $49^{\circ} \mathrm{C}$. All solutions contained chlorine (200 $\mu \mathrm{g} / \mathrm{ml})$ and Triton $\mathrm{X}-100$ (0.2 ml/liter). The fruit were not rinsed after treatment. Each treatment included four replicates of 27 lemon fruit each. Green mold incidence on lemon was evaluated after storage for 1 week at $20^{\circ} \mathrm{C}$ and $95 \%$ relative humidity. The experiment was done once.

Temperature, sodium bicarbonate, and chlorine influence on postharvest TBZ effectiveness. Light-green lemon fruit were inoculated using both TBZ-s and TBZ-r isolates as described previously. After $24 \mathrm{~h}$, they were immersed for $60 \mathrm{~s}$ in $\mathrm{TBZ}$ at $350 \mu \mathrm{g} / \mathrm{ml}$ alone or combined with sodium bicarbonate $\left(\mathrm{NaHCO}_{3} ; 3 \% \mathrm{wt} / \mathrm{vol}\right)$ and chlorine $(200 \mu \mathrm{g} / \mathrm{ml})$. The solution temperatures were 13 or $41^{\circ} \mathrm{C}$. The fruit were rinsed briefly with fresh tap water after treatment. Each treatment included three replicates of 75 lemon fruit each. Green mold incidence was evaluated after storage for 3 weeks at $10^{\circ} \mathrm{C}$ and $95 \%$ relative humidity. The experiment was done twice, once with $P$. digitatum TBZ-s isolate M6R and once with $P$. digitatum TBZ$r$ isolate D201.

Method of postharvest TBZ application and solution temperature on TBZ effectiveness. Light-green lemon fruit were inoculated as described previously. After $24 \mathrm{~h}$, they were immersed or drenched with an aqueous TBZ suspension that contained TBZ at $372 \mu \mathrm{g} / \mathrm{ml}$ alone or combined with sodium bicarbonate $(3 \%$ $\mathrm{wt} / \mathrm{vol})$ and chlorine $(200 \mu \mathrm{g} / \mathrm{ml})$. Fruit were either drenched or immersed for $60 \mathrm{~s}$ in the test solutions at 13 or $41^{\circ} \mathrm{C}$. Fruit were immersed in 29-liter-capacity jars, passed through a 2,000-liter-capacity tank, or they were drenched with a recirculated, low-pressure, high-volume (33.6 liters/min) spray. The tank (40) and drencher (41) were described in prior publications. Fruit were rinsed for several seconds with fresh water after the immersion treatments but 
not after the drench treatments. Each treatment was applied to three replicates of 75 lemon fruit each. Green mold incidence on fruit was evaluated after storage for 5 weeks at $10^{\circ} \mathrm{C}$ and $95 \%$ relative humidity. The experiment was done twice, once with $P$. digitatum TBZ-s isolate M6R and once with $P$. digitatum TBZ-r isolate D201.

Performance of postharvest TBZ, bicarbonate, and chlorine solutions with naturally inoculated orange fruit. Navel orange fruit were drenched in field bins before degreening to reduce decay. Naturally infected orange fruit in field bins were harvested from groves near Sanger, $\mathrm{CA}$, and treated in a packinghouse in Orange Cove, CA. Control fruit were untreated, whereas those treated were drenched for about $15 \mathrm{~s}$ with a recirculated solution containing TBZ $(350 \mu \mathrm{g} / \mathrm{ml})$, sodium bicarbonate $(3 \% \mathrm{wt} / \mathrm{vol})$, and chlorine $(200 \mu \mathrm{g} / \mathrm{ml})$ at the ambient temperature (about $15^{\circ} \mathrm{C}$ ), and then dried in air for several hours. All fruit then were placed for 2 days in ethylene at $5 \mu \mathrm{l} /$ liter at $20^{\circ} \mathrm{C}$ and 90 to $95 \%$ relative humidity and stored for an additional 7 days at $10^{\circ} \mathrm{C}$. Afterwards, they were placed on a commercial packing line, where the infected fruit were removed by hand and their number recorded. The test was repeated five times with orange fruit from different groves harvested in November and December 2002. The number of navel orange fruit examined from each treatment from groves $1,2,3,4$, and 5 was approximately 37,500 , $12,000,36,000,45,000$, and 36,000 , respectively.

Influence of postharvest TBZ concentration and solution temperature on TBZ residues. Uninoculated lemon fruit were immersed for $1 \mathrm{~min}$ in one of the test solutions at either 24 or $41^{\circ} \mathrm{C}$. TBZ content in the aqueous solutions was $0,150,250$, 500 , or $1,000 \mu \mathrm{g} / \mathrm{ml}$. Lemon fruit were dried in air before packing in plastic bags or cans. Each treatment consisted of four replicates 12 fruit each. The fruit were stored at $4^{\circ} \mathrm{C}$ and residues were determined within several days. The test was repeated twice.

Influence of pre- and postharvest treatments on fruit surface color during ethylene degreening. The rate of surface color change of the fruit in test 1 , where five fungicides had been applied to navel orange trees 1 week before harvest, was determined during ethylene degreening beginning immediately after harvest. Washington navel orange and Eureka lemon fruit that were dark green in color were either untreated (dry control) or immersed for $60 \mathrm{~s}$ in water (wet control), TBZ $(200 \mu \mathrm{g} / \mathrm{ml})$, sodium bicarbonate (3\% $\mathrm{wt} / \mathrm{vol}$ ), or a combination of TBZ and sodium bicarbonate. Fruit were not rinsed after treatment. The test was repeated twice with Washington navel orange fruit and once with Eureka lemon fruit. Each treatment included four replicates of 20 fruit each. The fruit were placed in ethylene at $5 \mu \mathrm{l} / 1$ at $20^{\circ} \mathrm{C}$ and 90 to $95 \%$ relative humidity. The rate of color change during ethylene degreening was determined using the Lab system of color notation (27) measured with a colorimeter (model CR200; Minolta Corp., Tokyo). L*, a*, and $b^{*}$ measurements were made initially and every $24 \mathrm{~h}$ thereafter and continued until most all green color was absent. Observations of a minimum of 40 fruit were recorded. $\mathrm{L}^{*}$ and calculated hue angle values were used for statistical analysis.

Residue analysis. Thiophanate methyl residues in fruit were determined using a method described by Gorbach (19). Fruit (three to five) were placed inside a steel can containing $100 \mathrm{ml}$ of methanol; the container was sealed and rolled slowly at 10 revolutions/min. After $45 \mathrm{~min}$, the container was removed, a portion of the methanol extract was passed through a paper filter (no. 1 Whatman), and $15 \mu \mathrm{l}$ was injected into a high-performance liquid chromatograph with a mobile phase of acetonitrile:water (40:60) with a UV detector operating at $235 \mathrm{~nm}$. TBZ residues were determined by the "Merck" method as described by Norman et al. (28). Twelve fruit within each replicate were extracted together as described previously, except with ethyl acetate instead of methanol. The surface-stripping solution was passed through a paper filter and the optical density measured with a spectrofluorometer at $360 \mathrm{~nm}$ with an excitation wavelength of $302 \mathrm{~nm}$.

Statistical analysis. The incidence of green mold in all experiments, except where the performance of postharvest TBZ, bicarbonate, and chlorine solutions with naturally inoculated orange fruit was assessed in a commercial packinghouse, was evaluated by an analysis of variance applied to the arcsin of the square root of the proportion of infected fruit. The fruit surface $\mathrm{L}^{*}$ and hue angle color measurements and fruit residue contents were analyzed by analysis of variance. Fisher's protected least significant difference test $(P \leq 0.05)$ was used to separate means. Actual values are shown. A paired $t$ test was applied to detect significant differences in the incidence of decay among the five groups of control and treated orange fruit in the commercial packinghouse test where the performance of postharvest TBZ, sodium bicarbonate, and chlorine solutions applied to naturally inoculated orange fruit was assessed.

\section{RESULTS}

Preharvest fungicide treatments. Although all fungicides used in this study significantly decreased postharvest green mold among degreened navel orange fruit, azoxystrobin and thiophanate methyl were the most effective and reduced the disease by 20.1 and $80.6 \%$, respectively (Table 1 ). Thiophanate methyl as a preharvest spray was the most effective fungicide and was selected for all subsequent grove experiments. None of the fungicides applied to navel orange trees in test 1 influenced the rate of color change (data not shown).

In subsequent tests, thiophanate methyl consistently reduced green mold among navel orange fruit by 78.1 to $90.8 \%$ compared with the untreated control when the fruit were harvested 1 week after application (Table 2). Residues of thiophanate methyl in fruit harvested 1 week after application were 0.3 to $3.6 \mu \mathrm{g} / \mathrm{g}$ fresh weight depending upon the method of application. In tests 4 and 5, green mold control persisted with some decline in effectiveness up to 7 weeks after application. In test 4 , thiophanate methyl residues persisted and increased slightly when measured repeatedly up to 7 weeks after application.

Postharvest fungicide treatments. TBZ effectively controlled green mold on lemon fruit at all concentrations and temperatures tested (Fig. 1). At $49^{\circ} \mathrm{C}$, significant control of green mold by the heatedwater treatment occurred and TBZ was very effective; treatment with TBZ at 100 $\mu \mathrm{g} / \mathrm{ml}$ almost eliminated green mold. Addition of sodium bicarbonate or heat to the TBZ solution significantly improved its effectiveness, even when a TBZ-r isolate of $P$. digitatum was used (Fig. 2). Among lemon fruit immersed for $1 \mathrm{~min}$ in $\mathrm{TBZ}$ at $350 \mu \mathrm{g} / \mathrm{ml}$ that also contained sodium bicarbonate $(3 \% \mathrm{wt} / \mathrm{vol})$ and chlorine (200 $\mu \mathrm{g} / \mathrm{ml})$, green mold incidence was significantly lower than among those treated with TBZ alone, at both 13 and $41^{\circ} \mathrm{C}$. Green

Table 1. Green mold incidence on navel orange fruit as affected by preharvest application of different fungicides ${ }^{y}$

\begin{tabular}{lllc}
\hline Product & \multicolumn{1}{c}{ Fungicide } & Rate $(\mathbf{k g} / \mathbf{h a})$ & Green mold $(\boldsymbol{\%})^{\mathbf{z}}$ \\
\hline Control & $\ldots$ & $\ldots$ & $98.9 \mathrm{a}$ \\
Switch & Cyprodinil + fludioxonil & $0.40+0.27$ & $95.8 \mathrm{~b}$ \\
Pristine & Boscalid + pyraclostrobin & $0.29+0.14$ & $92.0 \mathrm{bc}$ \\
Headline & Pyraclastrobin & 0.25 & $89.4 \mathrm{c}$ \\
Abound & Azoxystrobin & 0.25 & $79.0 \mathrm{~d}$ \\
Topsin M WSB & Thiophanate methyl & 1.58 & $19.2 \mathrm{e}$ \\
\hline
\end{tabular}

${ }_{\mathrm{y}}$ Fruit were harvested 1 week after application, inoculated with Penicillium digitatum isolate M6R, degreened for 3 days in air containing ethylene at $5 \mu \mathrm{l} /$ liter at $20^{\circ} \mathrm{C}$, then stored at $20^{\circ} \mathrm{C}$ for one additional week.

${ }^{\mathrm{z}}$ Values followed by unlike letters differ significantly by Fisher's protected least significant difference test $(P=0.05)$. An arcsin transform was applied before analysis of variance; actual values are shown. 
mold caused by both isolates was particularly reduced by treatment with the combination solution applied at $41^{\circ} \mathrm{C}$. Green mold caused by the TBZ-r isolate was reduced by the combination treatment at $41^{\circ} \mathrm{C}$ to $14 \%$, compared with about $55 \%$ with TBZ alone.

The method of application of TBZ significantly influenced its effectiveness. Immersion of lemon fruit for $1 \mathrm{~min}$ in a mixture that contained TBZ at $372 \mu \mathrm{g} / \mathrm{ml}$, sodium bicarbonate ( $3 \% \mathrm{wt} / \mathrm{vol})$, and chlorine $(200 \mu \mathrm{g} / \mathrm{ml})$, was more effective than drenching fruit with this solution for the control of green mold (Fig. 3). When fruit were immersed at the warmer $\left(41^{\circ} \mathrm{C}\right)$ temperature, it controlled both the TBZ-s and the TBZ-r isolates effectively. Heating the drencher solution did not improve its effectiveness.

Among naturally inoculated orange fruit treated with $\mathrm{TBZ}$, sodium bicarbonate, and chlorine at $15^{\circ} \mathrm{C}$ before degreening, the number of decayed fruit was significantly (paired $t$ test, $P<0.001$ ) reduced among fruit from all five groves compared with

Table 2. Influence of a preharvest application of thiophanate methyl (TM) on postharvest residues and the incidence of green mold ${ }^{u}$

\begin{tabular}{lcccccc}
\hline & & & & \multicolumn{2}{c}{ Green mold incidence (\%) $^{\mathbf{v}}$} & \\
\cline { 5 - 6 } Test & Interval $^{\mathbf{w}}$ & Rainfall $^{\mathbf{x}}$ & Residue $^{\mathbf{y}}$ & $\mathbf{T M}$ & Control & Reduction $^{\mathbf{z}}$ \\
\hline 1 & 1 & 1.0 & $\ldots$ & 17.4 & 79.4 & 78.1 \\
2 & 1 & 1.0 & 3.6 & 17.5 & 95.1 & 81.6 \\
3 & 1 & 16.5 & 0.3 & 8.9 & 96.9 & 90.8 \\
4 & 1 & 4.1 & 2.1 & 13.1 & 77.0 & 83.0 \\
& 3 & 28.5 & 4.8 & 6.8 & 80.4 & 91.5 \\
& 5 & 36.6 & 4.3 & 17.0 & 87.7 & 80.6 \\
& 7 & 67.6 & 5.1 & 26.0 & 90.5 & 71.3 \\
5 & 1 & 6.1 & $\ldots$ & 19.2 & 98.9 & 80.6 \\
& 4 & 27.5 & 1.8 & 41.2 & 99.1 & 58.4 \\
& 7 & 51.6 & $\ldots$ & 31.8 & 100.0 & 68.2 \\
\hline
\end{tabular}

u Navel orange fruit harvested 1 week after TM or water (control) applications were inoculated with spores of Penicillium digitatum isolate M6R, degreened immediately for 3 days in ethylene at 5 $\mu \mathrm{g} / \mathrm{ml}$ at $20^{\circ} \mathrm{C}$, then stored for an additional 4 days at $20^{\circ} \mathrm{C}$. Fruit harvested more than 1 week after TM or water treatment were inoculated with $P$. digitatum and stored for 1 week at $20^{\circ} \mathrm{C}$.

${ }^{v}$ Green mold determined after 7 days of storage at $20^{\circ} \mathrm{C}$ after degreening or harvest. Each value is the mean of four replicates containing 60 to 75 fruit each.

${ }^{\mathrm{w}}$ Interval (weeks) between application of treatments to trees and harvest.

${ }^{x}$ Rainfall $(\mathrm{mm})$ between application of the treatments and harvest.

${ }^{\mathrm{y}}$ Thiophanate methyl residues in fruit $(\mu \mathrm{g} / \mathrm{g}$ of fresh weight). Each value is the mean of two or three replicates of eight fruit each.

${ }^{\mathrm{z}}$ Percent reduction in green mold compared with the control.

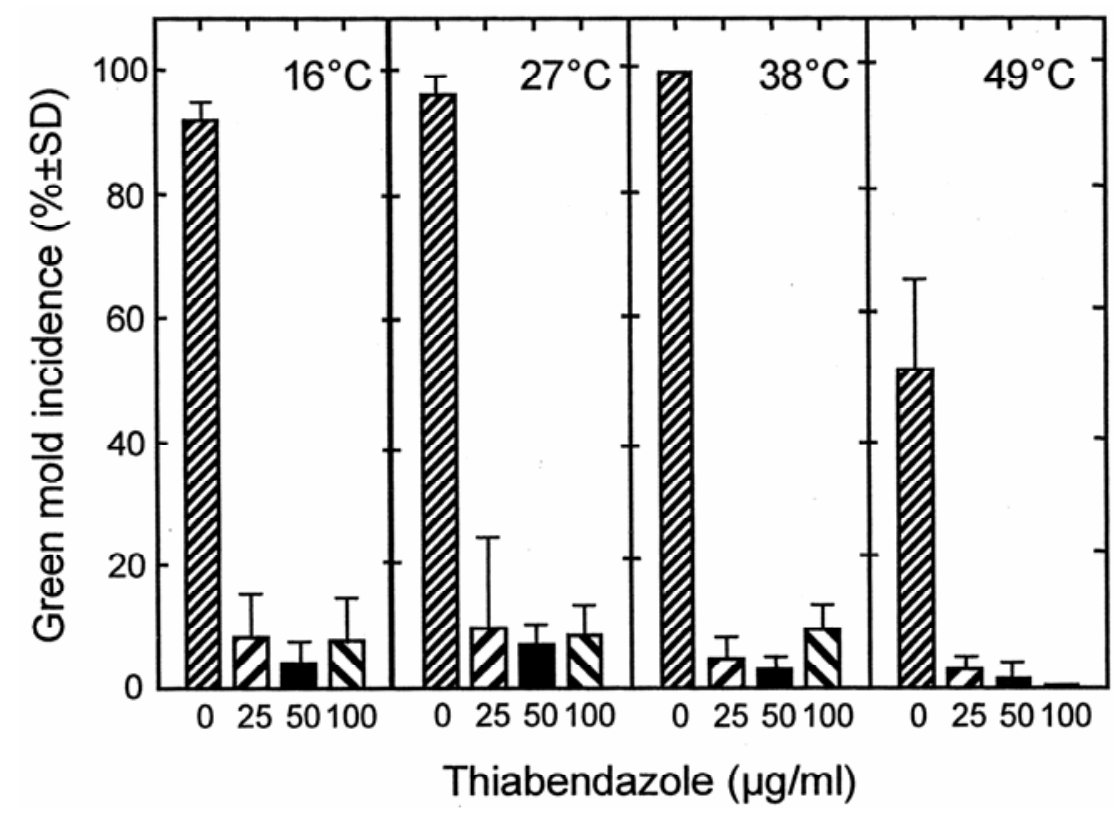

Fig. 1. Influence of thiabendazole (TBZ) solution temperature on its effectiveness to control green mold. Light-green lemon fruit were inoculated with spores of TBZ-sensitive isolate M6R of Penicillium digitatum. After $24 \mathrm{~h}$ at $20^{\circ} \mathrm{C}$, they were immersed for $60 \mathrm{~s}$ in aqueous solutions containing TBZ at $0,25,50$, or $100 \mu \mathrm{g} / \mathrm{ml}$ at temperatures of $16,27,38$, or $49^{\circ} \mathrm{C}$. All solutions contained chlorine (200 $\mu \mathrm{g} / \mathrm{ml})$ and Triton X-100 (0.2 ml/liter), and the fruit were not rinsed after treatment. Each treatment was applied to four replicates of 27 lemon fruit each. Green mold incidence was evaluated after storage for 1 week at $20^{\circ} \mathrm{C}$ and $95 \%$ relative humidity. untreated fruit (Fig. 4). The average incidence of decayed fruit among untreated fruit was about $11 \%$; whereas, among fruit that were drenched before degreening it was about $2 \%$. Green mold was the most commonly encountered disease.

TBZ residues within the fruit increased linearly when the aqueous TBZ concentration used to treat the lemon fruit increased from 150 to $1,000 \mu \mathrm{g} / \mathrm{ml}$ (Fig. 5). Raising the temperature of the TBZ solution from 24 to $41^{\circ} \mathrm{C}$ significantly increased the residues about 1.5- to 2-fold.

Change in the rind color expressed as change in hue angle (Fig. 6) was not significantly affected when navel orange fruit were treated with TBZ, sodium bicarbonate, or their combination. However, color change was slightly but significantly delayed in lemon fruit treated with sodium bicarbonate either alone or combined with TBZ.

\section{DISCUSSION}

We have observed that the ethylene degreening process, which in California entails exposure of the fruit to ethylene at 5 $\mu \mathrm{l} /$ liter for as long as 5 days, can be plagued by unacceptably high postharvest decay losses on citrus fruit. Green mold is the most important disease during degreening in California for several reasons. In Florida and other subtropical citrusgrowing climates, Diplodia stem-end rot, caused by Lasiodiplodia theobromae, is a common postharvest disease; whereas, in California and other arid growing areas, it is uncommon (18). Losses by Diplodia stem-end rot are greatly exacerbated by degreening (2), because ethylene both

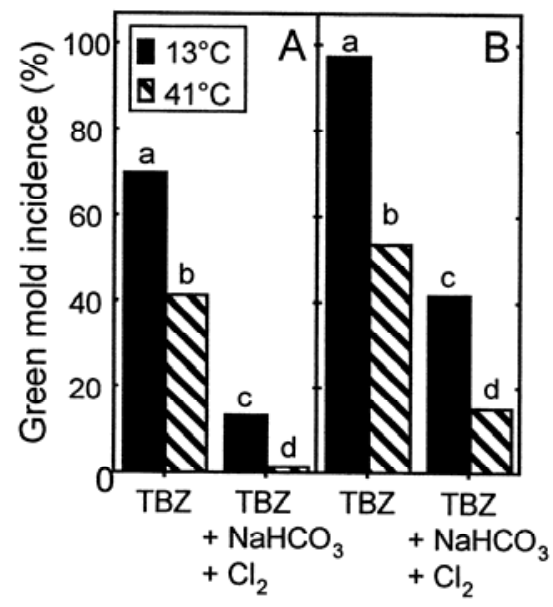

Fig. 2. Influence of the addition of sodium bicarbonate $(3 \% \mathrm{wt} / \mathrm{vol})$ and chlorine $(200 \mu \mathrm{g} / \mathrm{ml})$ and temperature on the effectiveness of immersion for $60 \mathrm{~s}$ in thiabendazole (TBZ; $350 \mu \mathrm{g} / \mathrm{ml}$ ) to control green mold on lemon fruit inoculated with A, TBZ-sensitive isolate M6R or B, TBZresistant isolate D201 of Penicillium digitatum. The fruit were stored for 3 weeks at $10^{\circ} \mathrm{C}$ before the number of infected fruit was counted. Each column is the mean of three replicates of 75 fruit. Columns within each panel with unlike letters differ significantly $(P \leq 0.05)$. 
stimulates the growth of this pathogen (11) and accelerates abscission enzymes that predispose fruit to infection (9). Conversely, ethylene does not stimulate $P$. digitatum growth and can even reduce green mold incidence slightly (29). Furthermore, partial control of green mold occurs during the relatively hightemperature $\left(28\right.$ to $\left.29^{\circ} \mathrm{C}\right)$ degreening conducted in Florida, which does not occur in California because degreening is conducted at cooler temperatures (20 to $21^{\circ} \mathrm{C}$ ) to minimize rind blemishes (20). Ethylene typically is applied to fruit in field bins, and packing line fungicide treatments necessarily are delayed until after the fruit are degreened and washed. However, because degreening can take as long as 5 days, these fungicide applications are too late and their effectiveness for the control of green mold is poor because the pathogen has invaded the rind too deeply by this time to be inhibited by the fungicide. Much better control can be achieved by applying the fungicide before degreening, as either a preharvest spray or postharvest drench, followed after degreening by additional packing line fungicide treatments (10). We found that both of these approaches, commonly employed in Florida, were very effective

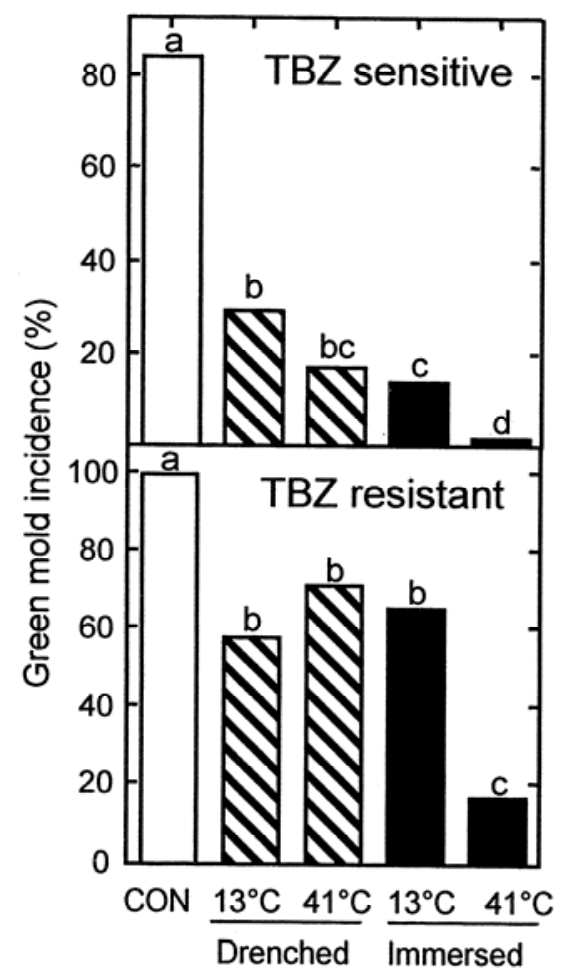

Fig. 3. Green mold incidence among lemon fruit treated with a solution containing sodium bicarbonate (3\% wt/vol), thiabendazole (TBZ; 350 $\mu \mathrm{g} / \mathrm{ml})$, and chlorine $(200 \mu \mathrm{g} / \mathrm{ml})$. The fruit were inoculated $24 \mathrm{~h}$ before treatment with a TBZsensitive (M6R) or a TBZ-resistant (D201) isolate of Penicillium digitatum. The solution was drenched over the fruit or they were immersed for $60 \mathrm{~s}$ before storage for 5 weeks at $10^{\circ} \mathrm{C}$. under California conditions with few modifications.

Thiophanate methyl applied once as a grove spray before harvest proved to be very effective in controlling green mold, even when the tests were conducted during rainy periods and the fruit were harvested and inoculated as long as 7 weeks following application (Tables 1 and 2). Protection was good, particularly when the fruit were picked 1 week after thiophanate methyl application, even when thiophanate methyl residues were as low as $0.3 \mu \mathrm{g} / \mathrm{g}$. Green mold did not develop in the rind injuries inoculated with spores of $P$. digitatum because the thiophanate methyl residue

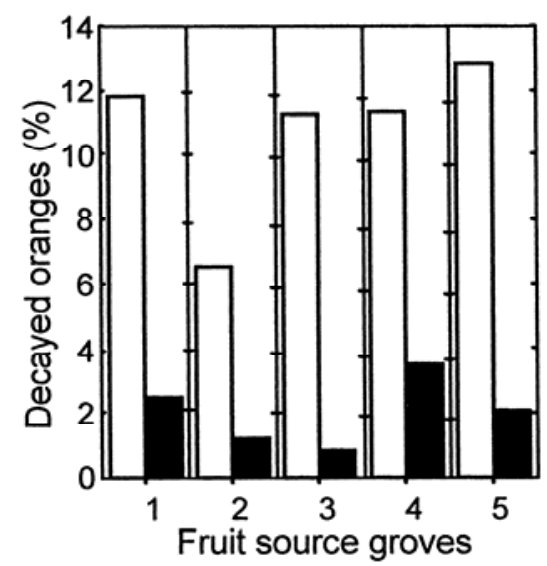

Fig. 4. Natural incidence of decayed orange fruit present after no treatment (white column) or drenching (black column) them in field bins for $15 \mathrm{~s}$ at $15^{\circ} \mathrm{C}$ with a solution containing thiabendazole $(350 \mu \mathrm{g} / \mathrm{ml})$, sodium bicarbonate $(3 \%$ $\mathrm{wt} / \mathrm{vol})$, and chlorine $(200 \mu \mathrm{g} / \mathrm{ml})$ in a commercial packinghouse. All fruit were exposed to ethylene at $5 \mu \mathrm{l} /$ liter for 2 days at $20^{\circ} \mathrm{C}$ followed by storage for 7 days in air at $10^{\circ} \mathrm{C}$. The numbers of orange fruit examined from each treatment from navel orange groves $1,2,3,4$, and 5 were approximately 37,500, 12,000, 36,000, 45,000 , and 36,000, respectively. The number of decayed orange fruit was significantly (paired $t$ test, $P<0.001$ ) lower after the drench treatment.

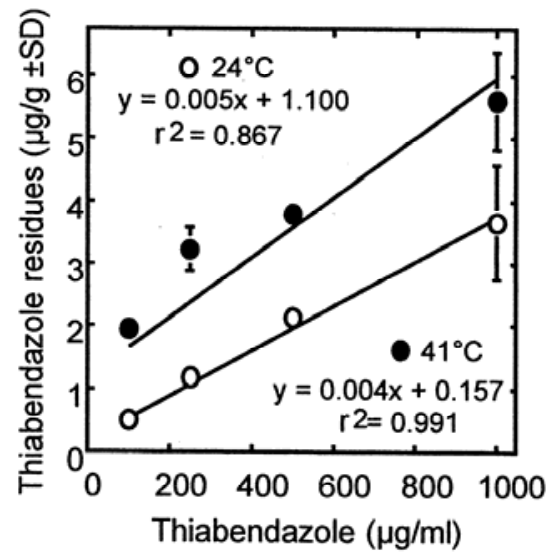

Fig. 5. Influence of thiabendazole solution concentration and temperature on its residues in lemon fruit. The fruit were immersed for $60 \mathrm{~s}$ in aqueous solutions of thiabendazole at 24 or $41^{\circ} \mathrm{C}$ and dried in air. Each value is the mean of four replicates of 12 lemon fruit each. within the rind, remaining from the grove application, had protected the fruit. In other citrus-growing areas, preharvest applications of benzimidazole fungicides consistently have been shown to control postharvest decay effectively when applied before harvest. Grove applications of benomyl $(7,12,45)$, TBZ $(3,10,35)$, carbendazim $(24,25)$, or thiophanate methyl $(24,31)$ all provided good to excellent control of postharvest decay. Presumably, this effectiveness is the result of their systemic activity and persistent residues.

Thiophanate methyl residues within orange fruit were persistent in our work, which explains why this fungicide protected the fruit effectively from infection during and after the degreening process. In test 4 , thiophanate methyl residues were significantly lower when measured 1 week after application than when sampled 3, 5, and 7 weeks later. Thiophanate methyl, benomyl, and carbendazim (methyl 2benzimidazolecarbamate) have the same mode of action (16) and their performance in many citrus applications is similar

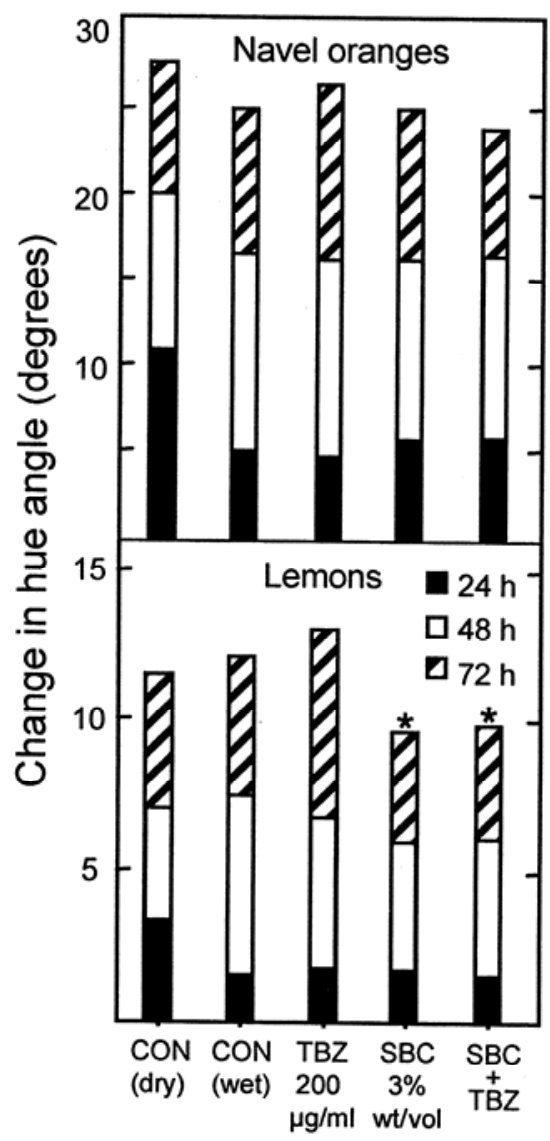

Fig. 6. Change in the rind surface color of navel orange and lemon fruit after immersion for $30 \mathrm{~s}$ in water, thiabendazole (TBZ; $200 \mu \mathrm{g} / \mathrm{ml}$ ), sodium bicarbonate (SBC; 3\% wt/vol), or a combination of SBC and TBZ. All treatments were followed by continuous exposure to ethylene gas at $5 \mu \mathrm{l} /$ liter at $20^{\circ} \mathrm{C}$. The initial hue angle ( \pm standard deviation) of the navel orange and lemon fruit was $106.9( \pm 1.7)$ and $109.1( \pm 1.8)$, respectively. Asterisks indicate significant differences $(P \leq 0.05)$. 
(24,31). Carbendazim, occasionally used alone as a fungicide, also is a product of benomyl or thiophanate methyl hydrolysis, although this hydrolysis occurs much more slowly with thiophanate methyl than benomyl (19). We measured carbendazim residues in tests 2 and 31 week after thiophanate methyl application and carbendazim residues were less than $0.1 \mu \mathrm{g} / \mathrm{g}$ (data not shown). Brown (4) and Brown and Albrigo (7) measured citrus fruit benomyl residues after it was applied to trees. They were able to detect residues, primarily of carbendazim, on Valencia orange fruit up to 70 days after application that were sufficient to reduce the incidence of green mold. They reported that the highest carbendazim residues in the flavedo and albedo were found 14 days after spraying, and that residues on fruit surfaces decreased whereas those within the peel increased for a period of time as carbendazim moved into the fruit. They found that residues of 0.1 to $0.9 \mu \mathrm{g} / \mathrm{g}$ in the orange fruit were measured after application of 1 to $1.5 \mathrm{lbs}$ of benomyl per acre, and residues of $0.14 \mu \mathrm{g} / \mathrm{g}$ were "marginal" to control green mold. In our work, thiophanate methyl residues of $0.3 \mu \mathrm{g} / \mathrm{g}$ were sufficient to give good protection of the fruit from infection. Brown (4) showed that carbendazim residues were relatively resistant to rainfall; 78 and $20 \%$ of the residues were removed by simulated rainfall applied immediately and 2 weeks after application, respectively.

When citrus fruit are wounded and inoculated after treatment, such as we did in the grove experiments, effective control of green mold typically requires a persistent systemic fungicide (21). This may explain the poor performance of the other locally systemic and nonsystemic fungicides in our trial (Table 1). Conversely, in packinghouses, both systemic and nonsystemic fungicides can be very effective, because these fruit are treated after wounding and inoculation have occurred as a consequence of harvest operations and subsequent handling before they are treated on packing lines (22). For example, although fludioxonil and azoxystrobin were not effective in our tests, they can very effectively control green mold when applied to inoculated fruit $(15,34)$. It is conceivable that nonsystemic fungicides could be effective treatments in grove applications, if they are able to inactivate sufficient inoculum in the grove to an extent that wounds inflicted during harvest are not inoculated because infective spores are not present.

The use of benzimidazole fungicides in Florida before degreening is a well-studied practice $(5,10)$. Aqueous preharvest sprays with benomyl or TBZ, or a postharvest drench application of TBZ applied before degreening, all effectively controlled decay, which was primarily Diplodia stemend rot. For effective control of Diplodia stem-end rot and green mold, a TBZ resi- due of at least $0.2 \mu \mathrm{g} / \mathrm{g}$ or greater on a whole fruit fresh weight basis was needed, and the residue must be present under the button and within injuries, where most fungal penetration occurs. TBZ bin treatments before degreening were more effective than treatments after degreening, because treatments applied afterward were too late to effectively stop these pathogens.

In our study, a TBZ-sensitive isolate (M6R) of $P$. digitatum was adequately controlled by TBZ at rates lower than 100 $\mu \mathrm{g} / \mathrm{ml}$ (data not shown). Raising the temperature of this $\mathrm{TBZ}$ solution to $49^{\circ} \mathrm{C}$ and the addition of sodium bicarbonate greatly increased its effectiveness (Fig. 1). The combination of TBZ, a higher solution temperature $\left(41^{\circ} \mathrm{C}\right)$, and sodium bicarbonate significantly controlled a TBZ-resistant isolate (D201) of $P$. digitatum (Figs. 2 and $3)$. Immersing the fruit in the solution was superior to drenching them with it. In the commercial trials, however, the fruit were drenched with an ambient-temperature chlorinated solution of TBZ and sodium bicarbonate and the treatment was effective enough that immersing the fruit in a heated solution was determined to be unnecessary. If TBZ-resistant isolates were present, or if the interval between harvest and treatment was prolonged, these added measures might be cost effective commercially.

The improved performance could be explained by an increase in TBZ residues caused by heat and the inhibition of the fungus by sodium bicarbonate (Fig. 5; 39). Residues of TBZ in citrus fruit are significantly correlated with TBZ concentration of the treatment suspension and solution temperature, but not related to the duration of the treatment $(14,33,43)$. Residues of TBZ in fruit after treatment at $50^{\circ} \mathrm{C}$ were about two-and-one-half times higher than those after treatment at $20^{\circ} \mathrm{C}(14)$. The higher residue levels detected following the warmer treatment could be due to an increase in the rate of diffusion of the fungicide across the plant cuticle.

The mechanism of synergy between sodium bicarbonate and TBZ is not known. Similar synergy was observed with imazalil and sodium bicarbonate (39). Sodium bicarbonate raises and buffers the $\mathrm{pH}$ of the TBZ solution (which may increase TBZ residues); $\mathrm{pH}$ above 8 inhibits $P$. digitatum growth, and sodium bicarbonate inhibits $P$. digitatum, even at neutral $\mathrm{pH}$ (39). Wardowski and coworkers (43) found that fruit residues of TBZ increased linearly when the aqueous TBZ solution $\mathrm{pH}$ increased; residues after treatment with TBZ solutions at $\mathrm{pH} 7.9$ and 10.8 were about 0.5 and $1.4 \mu \mathrm{g} / \mathrm{g}$, respectively. The $\mathrm{pK}_{\mathrm{a}}$ of $\mathrm{TBZ}$ is 5.82 (at $25^{\circ} \mathrm{C}$ and ionic strength of $0.1 \mathrm{M})(1)$; therefore, as $\mathrm{pH}$ increases, TBZ water solubility decreases. The increase in TBZ effectiveness we observed could be related to the increase in $\mathrm{pH}$ caused by the addition of sodium bi- carbonate. TBZ residues in fruit treated with the flood recovery system were higher than would be expected with the aqueous spray or water wax application systems (43). This supports our findings that, when drenching and immersion methods of TBZ application were compared, the immersed fruit showed much lower green mold incidence than drenched ones. In most of the world, the residue tolerance of TBZ for citrus fruit is 10 $\mathrm{mg} / \mathrm{kg}$ (whole fruit basis) and fruit in our tests did not exceed this.

In this work, we found that TBZ performance was improved by sodium bicarbonate, so that even a TBZ-resistant isolate of $P$. digitatum was controlled. Recently, we observed similar improvement in imazalil performance where control of imazalil-resistant isolates occurred when it was combined with sodium bicarbonate (39). Addition of sodium bicarbonate to these fungicides is particularly useful in packinghouses, where isolates resistant to both fungicides are common. Although sodium bicarbonate improved fungicide performance, disposal of the used and soiled fungicide solutions is made more difficult by its presence because of its high salt content and $\mathrm{pH}$. Sodium bicarbonate residues increase the rate of fruit water loss, particularly if the fruit are not waxed after treatment and the salt residue remains on them for prolonged periods. Sodium bicarbonate also slightly but significantly delayed the color development of lemon fruit, but not navel orange fruit, during ethylene degreening.

A favorable aspect of both benzimidazole fungicides and postharvest heat treatments is that they can improve the rind quality of citrus fruit during prolonged cold storage by reducing chilling injury. Postharvest treatments with TBZ or benomyl reduced the incidence of chilling injury in grapefruit as expressed by peel pitting (32). Postharvest treatments with TBZ at $1,200 \mu \mathrm{g} / \mathrm{ml}$ at room temperature or at $200 \mu \mathrm{g} / \mathrm{ml}$ at $50^{\circ} \mathrm{C}$ resulted in similar TBZ residues in Tarocco orange fruit, although $\mathrm{TBZ}$ treatments at $50^{\circ} \mathrm{C}$ more effectively reduced chilling injury symptoms (37). Susceptibility of grapefruit and orange to chilling injury could be reduced by dipping fruit in hot TBZ either before, or in conjunction with, packing line treatments $(36,44)$. The reduction of chilling injury in 'Star Ruby' grapefruit caused by TBZ is not related to its fungicidal properties but may be related to its antioxidant properties, which are stimulated in flavedo tissue by both TBZ and heat treatment (37). Lower doses of TBZ applied with heat were more effective in reducing chilling injury compared with higher doses at room temperature.

In this work, we show two methods, similar to each other in effectiveness, that can minimize postharvest green mold losses that occur during degreening in 
California. Preharvest applications of thiophanate methyl did not influence the rate of rind color change during degreening, whereas postharvest treatments containing sodium bicarbonate either alone or with TBZ resulted in detectable but minor delay in the rate of color change of lemon fruit during degreening. The cost of these treatments is not prohibitive when compared with the value of the fruit lost without them when disease incidence is high. Preharvest treatment of trees with thiophanate methyl is a useful option for fruit growers, particularly because only one application was needed and the protection it provided was very persistent. This treatment is best used only in seasons conducive to significant green mold losses because, if used repeatedly, it could lead to the development of thiophanate methylresistant isolates in groves, which would also be resistant to TBZ used in packinghouses. Postharvest bin drenching with TBZ and sodium bicarbonate is a practice that would be implemented by packinghouse managers. Sodium bicarbonate and heat enhanced TBZ activity such that even a TBZ-resistant isolate of $P$. digitatum was controlled.

\section{ACKNOWLEDGMENTS}

We thank J. Doctor and R. Elliott of Sunkist Growers Fruit Sciences for many useful ideas and encouragement; R. Whitson of Cerexagri for the donation of materials, fungicide residue analysis, and other assistance; S. Wartanessian and M. Sales of Decco Cerexagri for fungicide residue analysis and other advice; J. Maze and W. Stutzman of the University of California Lindcove Citrus Research and Extension Center for the use of their groves and packing line facility; and manager $\mathrm{K}$. Bramer of the Harding and Leggett packinghouse in Orange Cove, CA, for conducting large-scale commercial tests with TBZ and sodium bicarbonate. This work was done with financial assistance supplied by the California Citrus Research Board.

\section{LITERATURE CITED}

1. Alvarez, J. L.M., Calzon, J. G., and Fonseca, J. M. L. 1997. Determination of $\mathrm{pK}_{\mathrm{a}}$ for protonated thiabendazole and the stability constant for the $\mathrm{Ni}(\mathrm{II})$-thiabendazole complex from catalytic polarographic currents. Bull. Soc. Chim. Belges 106:733-736.

2. Barmore, C. R., and Brown, G. E. 1985. Influence of ethylene on increased susceptibility of oranges to Diplodia natalensis. Plant Dis. 69:228-230.

3. Brown, G. E. 1968. Experimental fungicides applied preharvest for control of postharvest decay in Florida citrus fruit. Plant Dis. Rep. 52:844-847.

4. Brown, G. E. 1974. Postharvest citrus decay as affected by Benlate applications in the grove. Proc. Fla. State Hortic. Soc. 87:237-240.

5. Brown, G. E. 1977. Application of benzimidazole fungicides for citrus decay control. Proc. Int. Soc. Citricult. 1:273-277.

6. Brown, G. E. 1986. Diplodia stem-end rot, a decay of citrus fruit increased by ethylene degreening treatment and its control. Proc. Fla. State Hortic. Soc. 99:105-108.

7. Brown, G. E., and Albrigo, L. G. 1972. Grove application of benomyl and its persistence in orange fruit. Phytopathology 62:1434-1438.

8. Brown, G. E., and Baraka, M. A. 1996. Effect of washing sequence and heated solutions to degreened Hamlin oranges on Diplodia stem- end rot, fruit colour and phytotoxicity. Proc. Int. Soc. Citricult. 2:1164-1170.

9. Brown, G. E., and Burns, J. K. 1998. Enhanced activity of abscission enzymes predisposes oranges to invasion by Diplodia natalensis during ethylene degreening. Postharvest Biol. Technol. 14:217-227.

10. Brown, G. E., and Craig, J. O. 1989. Effectiveness of aerosol fungicide applications in the degreening room for control of citrus fruit decay. Proc. Fla. State Hortic. Soc. 102:181-185.

11. Brown, G. E., and Lee, H. S. 1993. Interactions of ethylene with citrus stem-end rot caused by Diplodia natalensis. Phytopathology 83:1204-1208.

12. Brown, G. E., and McCornack, A. A. 1969. Benlate, an experimental preharvest fungicide for control of postharvest citrus fruit decay. Proc. Fla. State Hortic. Soc. 81:39-43.

13. Brown, G. E., and Miller, W. R. 1999. Maintaining fruit health after harvest. Pages 175188 in: Citrus Health Management. L. W. Timmer and L. W. Duncan, eds. The American Phytopathological Society Press, St. Paul, MN.

14. Cabras, P., Schirra, M., Piriei, F. M., Garau, V. L., and Angioni, A. 1999. Factors affecting imazalil and thiabendazole uptake and persistence in citrus fruits following dip treatments. J. Agric. Food Chem. 47:3352-3354

15. Cochran, A., Tally, A., and Tedford, E. 2003. Evaluation of tank mixtures of fludioxonil and azoxystrobin for postharvest disease control on citrus. (Abstr.) Phytopathology 93:S17.

16. Davidse, L. C. 1986. Benzimidazole fungicides: Mechanism of action and biological impact. Annu. Rev. Phytopathol. 24:43-65.

17. Eckert, J. W., and Brown, G. E. 1986. Evaluation of postharvest treatments for citrus fruits. Pages 92-97 in: Methods for Evaluating Pesticides for Control of Plant Pathogens. K. D. Hickey, ed. American Phytopathological Society, St. Paul, MN.

18. Eckert, J. W., and Eaks, I. L. 1989. Postharvest disorders and diseases of citrus fruits. Pages 179-260 in: The Citrus Industry, vol. V. W. Reuther, E. Calavan, E. C., and G. E. Carman, eds. University of California Press, Riverside.

19. Gorbach, S. 1980. A review of methods for the residue analysis of the systemic fungicide benomyl, carbendazim, thiophanate methyl, and thiabendazole. Pure Appl. Chem. 52:25692590.

20. Grierson, W. Cohen, E., and Kitagawa, H. 1986. Degreening. Pages 253-274 in: Fresh Citrus Fruits. W. F. Wardowski, S. Nagy, and W. Grierson, eds. AVI Book of Van Nostrand Reinhold Company, New York.

21. Gutter, Y. 1969. Comparative effectiveness of benomyl, thiabendazole, and other antifungal compounds for postharvest control of Penicillium decay in Shamouti and Valencia oranges. Plant Dis. Rep. 53:474-478.

22. Gutter, Y. 1969. Effectiveness of preinoculation and postinoculation treatments with sodium orthophenate, thiabendazole, and benomyl for green mold control in artificially inoculated Eureka lemons. Plant Dis. Rep. 53:479-482.

23. Jahn, O. L., Cubbedge, R. H., and Smoot, J. J. 1970. Effect of washing sequence on the degreening response and decay of some citrus fruits. Proc. Fla. State Hortic. Soc. 83:217-221.

24. Kuramoto, T. 1976. Resistance to benomyl and thiophanate-methyl in strains of Penicillium digitatum and P. italicum in Japan. Plant Dis. Rep. 60:168-172.

25. Ladaniya, M. S., and Singh, S. 1998. Postharvest technology of Nagpur mandarin Citrus reticulata Blanco. Tech. Bull. 2, NRC Citrus, Nagpur, India.

26. McCornack, A. A. 1972. Effect of ethylene degreening on decay of Florida citrus fruit. Citrus Ind. 53:14-15.

27. McGuire, R. G. 1992. Reporting of objective color measurements. HortScience 27:12541255 .

28. Norman, S. M., Fouse, D. C., and Craft, C. C. 1972. Thiabendazole residues on and in citrus fruit. Agric. Food Chem. 20:1277-1230.

29. Porat, R., Weiss, B., Cohen, L., Daus, A., Goren, R., and Droby, S. 1999. Effects of ethylene and 1-methylcyclopropene on the postharvest qualities of "Shamouti" oranges. Postharvest Biol. Technol. 15:155-163.

30. Ritenour, M. A., Miller, W. M., and Wardowski, W. W. 2003. Recommendations for Degreening Florida Fresh Citrus Fruits. Circular 1170. Horticultural Sciences Department, Florida Cooperative Extension Service, IFAS, University of Florida, Gainesville.

31. Ritenour, M. A., Pelosi, R. R., Burton, M. S., Stover, E. W., Dou, H., and McCollum, T. G. 2004. Assessing the efficacy of preharvest fungicide applications to control postharvest diseases of Florida citrus. HortTechnology 14:5862.

32. Schiffmann-Nadel, M., Chalutz, E., Waks J., and Dagan, M. 1975. Reduction of chilling injury in grapefruit by thiabendazole and benomyl during long-term storage. J. Am. Soc. Hortic. Sci. 100:270-272.

33. Schirra, M., Angioni, A., Ruggiu, R., Minelli, E. V., and Cabras, P. 1998. Thiabendazole uptake and persistence in lemons following postharvest dips at $50^{\circ} \mathrm{C}$. Ital. J. Food Sci. 10:165170.

34. Schirra, M., Cabras, P., Angioni, A., and Brandolini, V. 2002. Residue levels and storage decay control in cv. Star Ruby grapefruit after dip treatments with azoxystrobin. J. Agric. Food Chem. 50:1461-1464.

35. Schirra, M., Cabras, P., Angioni, A., D'hallewin, G., and Pala, M. 2002. Residue uptake and storage responses of Tarocco blood oranges after preharvest thiabendazole spray and postharvest heat treatment. J. Agric. Food Chem. 50:2293-2296.

36. Schirra, M., D'hallewin, G., Cabras, P., Angioni, A., Ben-Yehoshua, S., and Lurie S. 2000. Chilling injury and residue uptake in cold-stored 'Star Ruby' grapefruit following thiabendazole and imazalil dip treatments at 20 and $50^{\circ} \mathrm{C}$. Postharvest Biol. Technol. 20:91-98.

37. Schirra, M., D'hallewin, G., Cabras, P., Angioni, A., and Garau, V. L. 1998. Seasonal susceptibility of Tarocco oranges to chilling injury as affected by hot water and thiabendazole postharvest dip treatments. J. Agric. Food Chem. 46:1177-1180.

38. Smilanick, J. L., Aiyabei, J., Mlikota Gabler, F., Doctor, J., Sorenson, D., and Mackey, B. 2002. Quantification of the toxicity of aqueous chlorine to spores of Penicillium digitatum and Geotrichum citri-aurantii. Plant Dis. 86:509514.

39. Smilanick, J. L., Mansour, M. F., Margosan, D. A., Mlikota Gabler, F., and Goodwine, W. R. 2005. Influence of $\mathrm{pH}$ and $\mathrm{NaHCO}_{3}$ on the effectiveness of imazalil to inhibit germination of spores of Penicillium digitatum and to control postharvest green mold on citrus fruit. Plant Dis. 89:640-648.

40. Smilanick, J. L., and Sorenson, D. 2001. Control of postharvest decay of citrus fruit with calcium polysulfide. Postharvest Biol. Technol. 21:157-168.

41. Smilanick, J. L., Sorenson, D., Mansour, M., Aieyabei, J., and Plaza, P. 2003. Impact of a brief postharvest hot water drench on decay, fruit appearance, and microbe populations of California lemons and oranges. HortTechnology 13:333-338.

42. Timmer, L. W. 1999. Diseases of fruit and foliage. Pages 107-115 in: Citrus Health Management. L. W. Timmer and L. W. Duncan, eds. The American Phytopathological Society Press, St. Paul, MN

43. Wardowski, W. F., Hayward, F. W. and Dennis, 
J. D. 1974. A flood-recovery TBZ fungicide treatment system for citrus fruits. Proc. Fla. State Hortic. Soc. 87:241-243.

44. Wild, B. L. 1993. Reduction of chilling injury in grapefruit and oranges stored at $1^{\circ} \mathrm{C}$ by prestorage hot dip treatments, curing, and wax application. Aust. J. Exp. Agric. 33:495-498.

45. Yildiz, F., Kinay, P., Yildiz, M., Sen, F., and Karacali, I. 2005. Effects of preharvest applications of $\mathrm{CaCl}_{2}, 2,4-\mathrm{D}$ and benomyl and postharvest hot water, yeast and fungicide treatments on development of decay on Sat- suma mandarins. J. Phytopathol. 153:94-98. 46. Zhang, J., and Swingle, P. P. 2005. Effects of curing on green mold and stem-end-rot of citrus fruit and its potential application under Florida packing system. Plant Dis. 89:834840. 